\title{
HAMBATAN DALAM MENERAPKAN SISTEM INFORMASI MANAJEMEN DALAM \\ DUNIA PENDIDIKAN DAN CARA MENGATASINYA
}

\author{
Artikel \\ Matakuliah Sistem Informasi Manajemen \\ DESI SEPTRIANI no absen 15 \\ Nim 17002039 \\ Email: Desiseptriani18@gmail.com
}

\begin{abstract}
Abstrak
Dalam menerapkan sistem informasi manajemen dalam dunia pendidikan pasti akan menemukan hambatan-hambatan dalam menerapkan sistem informasi ini dengan melakukan perubahan-perubaha terhadap sistem yang lama. Dalam artikel ini akan dikaji apa-apa saja hambatan yang ditemukan dalam menerapkan sistem informasi manajemen dalam dunia pendidikan dan bagaimana cara mengatasinya karena tidak semua penerapan dengan sistem yang baru akan berjalan dengan lancar dan diterima dengan baik oleh pihak yang bersangkutan.
\end{abstract}

\section{Keyword: hambatan, sistem, informasi, manajemen}

\section{Pendahuluan}

Dalam setiap kegiatan pastinya akan ada sebuah manajemen yang mengatur jalannya kegiatan tersebut, begitu juga dengan dunia pendidikan yang mana setiap kegiatan dalam dunia pendidikan juga akan ada sebuah manajemen yang mengatur kegiatan tersebut dengan sistem yang berbeda-beda. Pada perkembangan zaman saat sekarang ini mulai berkembangnya sebuah sistem dalam dunia pendidikan maupun organisasi lainnya yang berhubungan dengan pengolahan data-data yaitu sistem informasi manajamen yang memudahkan sebuah instansi baik itu bagi atasan maupun bagi bawahan dalam melakukan pekerjaannya karena didukkung dengan teknologi-teknologi yang sesuai dengan perkembangan zamannya.

Namun dalam penerapan sistem informasi manajemen ini dalam dunia pendidikan pastinya akan menghadapi permasalahan-permasalahan yang dapat menghambat jalannya sistem ini dengan beberapa permasalahan baik dari pengetahuan bawahan yang kurang memahami bagaimana menggunakan sistem informasi manajemen ini dan lain sebagainya. Oleh sebab itu, berdasarkan uraian tersebut dapat dirumuskan masalah yang akan di uraikan berupa 1) pengertian sistem informasi manajemen, 2) apa tujuan dari penggunaan sistem informasi 
manajemen, 3) apa manfaat pentingnya sistem informasi manajemen bagi dunia pendidikan, 4) apa saja hambatan dalam menerapkan sistem informasi manajemen dalam dunia pendidikan dan cara mengatasinya. Dan tujuan dari penulisan artikel ini adalah agar dapat mengetahui apa itu sistem informasi manajemen, mengetahui tujuan dari sistem informasi manajemen, manfaat pentingnya sistem informasi manajemen dan bagaimana hambatan yang ditemukan dalam menerapkan sistem informasi manajemen dalam dunia pendidikan dan cara mengatasinya.

\section{Pembahasan}

\section{Konsep dasar sistem informasi manajemen}

\section{Pengertian sistem}

Sistem merupakan suatu kesatuan yang memiliki unsur-unsur atau komponen-komponen penunjang yang tidak dapat di pisahkan satu sama lainnya agar dapat mencapai tujuan yang di inginkan.

\section{Pengertian informasi}

Informasi adalah suatu data yang sudah diolah yang dapat digunakan untuk pengambilan keputusan yang mana informasi tersebut sudah nyata dan sudah dapat dibuktikan kebenarannya. Informasi juga bisa disebut dengan pesan yang mana pesan tersebut sudah dapat diketahui kebenaran dari isinya.

\section{Pengertian manajamen}

Manajemen dalam artian luas adalah suatu proses atau rangkaian kegiatan yang dilaksanakan oleh dua orang atau lebih untuk mencapai tujuan yang telah ditentukan yang dimulai dari perencanaan, pengelompokaan, pelaksanaan dan pengawasan ( planning, organization, actuating, and controling) secara efektif dan efesien.

\section{Pengertian sistem informasi manajemen}

Sistem informasi manajemen yang saat ini sangat berkembang didunia kerja maupun dalam dunia pendidikan. Sistem informasi manajemen adalah suatu rangkaian sistem yang digunakan untuk mengumpulkan suatu informasi yang mana informasi tersebut dapat berguna untuk pengambilan keputusan dan dapat mendukung fungsi-fungsi operasi manajemen dalam sebuah organisasi ataupun dalam dunia pendidikan. Bagi seorang atasan sistem informasi manajemen dapat digunakan untuk pengambilan keputusan dalam manajemen dan kebijakan kebijkan yang akan dikeluarkan karena informasi yang telah di rangkum dengan baik dan 
kongkrit, sedangkan bagi bawahan sistem informasi manajemen berguna untuk perencanaan operasional yang akan dilaksanakan atau dijalankan nantinya.

Menurut dewi dan sabandi (Dewi \& Sabandi, 2019) Sitem informasi juga dapat digunakan untuk meningkatan mutu terkait dalam pencapaian mutu pendidikan untuk itu diperlukan seorang tenaga kependidikan dan pendidik yang memahami sistem informasi sehingga mereka dapat menunjukkan profesionalisme agar dapat menjalankan tugasnya masingmasing.

Menurut sabandi dalam (Sabandi, 2019) sistem informasi manajemen merupakan sebuah sistem atau rangkaian yang terdiri dari beberapa unsur-unsur atau komponen-komponen yag saling berkaitan satu sama lain dan tidak bisa dipisahkan, yang mana dari sistem sistem tersebut pasti akan saling terkoordinasi satu sama lain agar dapat mencapai tujuan yang akan dicapai. Dari komponen kompone tersebut dapat diliat ada tiga kegiatan utama dalam sistem tersebut yaitu menerima dan masukan ( input), penghitungan data, penggabungan data sehingga di dapatkan pengeluaran (input) yang dapat digunakan berupa informasi yang beriskan data-data yang telah benar adanya atau kongkret.

Dari penjelasan di atas dapat kita simpulkan bahwasannya sistem informasi manajemen dalam dunia pendidikan adalah suatu rangkaian sistem yang digunakan untuk mengumpulkan informasi yang dapat digunakan untuk pengambilan keputusan dan mendukung fungsi-fungsi manajemen dalam dunia pendidikan untuk mencapai tujuan pendidikan yang telah direncanakan.

\section{Tujuan sistem informasi manajemen dalam dunia pendidikan}

Tujuan dari sistem informasi manajemen dalam dunia pendidikan secara khusus adalah untuk menyediakan dan menyusun bagaimana rangkaian kegiatan atau sistematika dari infrmasi yang di perlukan yang nantinya dapat digunakan dengan sebaik mungkin dan se efisen mungkin untuk mencapai tujuan pendidikan. Karena dari output yang dikeluarkan dalam sistem informasi tersebut sangat berguna dan membantu sekali dalam melaksanakan fungsi-fungsi manajemen terutama di pendidikan yaitu sekolah, dengan adanya informasi yang tersusun dengan rapi dan memiliki sistematika yang dapat memudahkan pekerjaan seorang manajer dalam mengelola informasi disekolah tersebut.

\section{Manfaat dari pentingnya penggunaan sistem informasi manajemen dalam dunia pendidikan}


ada beberapa manfaat dari penggunaan sistem informasi manajemen untuk dunia pendidikan yaitu:

1. Pihak sekolah dapat dengan mudah mengelola data-data siswa yang ada disekolah

2. Dapat mengelola nilai-nilai siswa berupa hasil ujian siswa baik ujian semester maupun ujian akhir, data nilai harian dan seluruh data menyangkut kegiatan akademik siswa dengan rapi dan efektif

3. Dapat mengelola data-data guru dan data tenaga kependidikan dengan akurat dan memudahkan kepala sekolah dalam mengawasi data tersebut.

4. Dapat juga digunakan untuk mengelola keuangan sekolah menggunakan sistem informasi yang benar sehingga dapat diketahui darimana dan untuk apa keuangan sekolah tersebut di belanjakan

5. Bisa bermanfaat juga untuk pengelolaan data pustaka di sekolah dengan pengelolaan sistem informasi.

Dengan menggunakan sistem informasi manajemen ini juga memiliki manfaat yang berguna untuk memudahkan sekolah dalam penerimaan murid baru sesuai dengan perkembangan teknologi pada saat sekarang ini, sehingga sekolah dan juga masyarakat yakninya orang tua murid tidak perlu lagi menggunakan sistem yang lama yang lebih banyak membuang-buang waktu dan tenaga karena sudah dibantu dengan penggunaan sistem informasi manajemen dengan data-data yang sudah diolah dan di kumpulkan dengan baik.

\section{Hambatan dalam menerapkan sistem informasi manajemen pendidikan dan cara mengatasinya}

Hambatan yang ditemukan dalam menerapkan sistem informasu manajemen dalam dunia pendidikan dapat berupa kelengkapan fasilitas yang ada, karena sistem informasi manajemen ini lebih kepada penggunaan teknologi komputer yang digunakan untuk dapat mengelola data-data yang dibutuhkan. Oleh sebab itu, jika fasilitas penunjang dari penggunaan sistem ini masih kurang dan tidak dapat memenuhi kebutuhan dalam mengolah data tersebut maka itu akan menjadi suatu penghambat bagi kelancaran penggunaan sistem ini. Jadi, cara mengatasi hal tersebut adalah kepala sekolah harus memperhatikan bagaimana fasilitas penunjang yang akan digunakan sehingga dapat dilaksanakan sistem informasi manajamen dengan efesien dan se efektif mungkin. 
Hambatan lainnya dalam penerapan sistem informasi manajemen disekolah ini adalah kurangnya pengetahuan dan keterampilan tentang bagaimana penggunaan sistem ini dan bagaimana cara mengoperasikannya sedemikian rupa sehingga dapat berfungsi dengan baik dan dapat di manfaatkan. Maka solusi untuk mengatasi hal tersebut adalah dengan cara memberikan pelatihan atau pelajaran kepada guru-guru sebelum menerapkan sistem ini sehingga guru yang akan menggunakan sistem ini dapat memahami bagaimana cara mengelola suatu data yang akan digunakan nantinya.

\section{PENUTUP}

\section{Kesimpulan}

Sistem informasi manajemen pendidikan adalah suatu rangkaian sistem yang digunakan untuk mengumpulkan informasi yang dapat digunakan untuk pengambilan keputusan dan mendukung fungsi-fungsi manajemen dalam dunia pendidikan untuk mencapai tujuan pendidikan yang telah direncanakan.yang mana dalam penerapannya akan ditemukan beberapa hambatan seperti kurangnya fasilitas yang memadai untuk penggunaan sistem informasi disekolah dan kurangnya kemampuan dan pengetahuan dari guru-guru yang akan menggunakan sistem ini sehingga mereka kesulitan dalam menerapkan sistem ini dan membuat sistem ini tidak berjalan dengan baik.

\section{Saran}

Diharapkan agar dapat mengatasi hambatan-hambatan dalam menerapkan sistem informasi manajemen tersebut dan dapat menerapkan sistem ini dengan sebaik mungkin dan se efesien mungkin.

\section{Daftar pustaka}

Dewi, A. P., \& Sabandi, A. (2019). Persepsi Guru Dalam Meningkatkan Mutu Pendidikan Berbasis Sistem Informasi Manajemen Di Sekolah Dasar Negeri 08 Batang Anai. Jurnal Bahana Manajemen Pendidikan. Retrieved from https://osf.io/w275f/download

Ramadanti, G. B., \& Sabandi, A. (2019). Persepsi Pegawai Terhadap Penerapan Sistem Informasi Manajemen Kepegawaian (SIMPEG) di BADAN KEPEGAWAIAN DAERAH PROVINSI SUMATERA BARAT. Jurnal Bahana Manajemen Pendidikan, 8(3), 8. Retrieved from http://103.216.87.80/index.php/bahana/article/view/105726/pdf

Rusdiana, . A., \& Irfan, M. (2014). Sistem Informasi Manajemen (Ctakan 1; B. A. Saebani, ed.). Retrieved from http://digilib.uinsgd.ac.id/8790/1/Buku Sistem Informasi Manajemen.pdf 
Syafrizal, M. (2007). Standar Sistem Mana jemen Keamanan Informasi. Seminar Nasional Teknologi, 1-10. Retrieved from https://s3.amazonaws.com/academia.edu.documents/42934378/58__ISO_17799_Standar_Sistem_Manajemen_Keamanan_Informasi14082009.pdf?responsecontent-disposition $=$ inline $\% 3 \mathrm{~B}$ filename\%3DISO_17799_Standar_Sistem_Manajemen_Keama.pdf\&X-AmzAlgorithm=AWS4-HMAC-SHA256\&X-Amz-

Credential=AKIAIWOWYYGZ2Y53UL3A\%2F20191013\%2Fus-east-

1\%2Fs3\%2Faws4_request\&X-Amz-Date $=20191013 \mathrm{~T} 014305 Z \& X$-Amz-Expires $=3600 \& X$ Amz-SignedHeaders $=$ host $\& X-A m z-$

Signature=be7be17f6e402425bc208315ac25ab80d817364833b81d61e07be8eb5ff59301 